\title{
Generalized Anxiety Disorder Tokoh Akiko dalam Drama Okaasan Musume wo Yamete Ii Desuka Karya Tomochika Kasaura
}

\author{
Ayu Bintang Tiara Maharani \\ Program Studi Sastra Jepang Fakultas Ilmu Budaya \\ [bintang_tiara23@yahoo.com]
}

\begin{abstract}
The title of this research is "The Generalized Anxiety Disorder of Akiko Figure in Okaasan Musume wo Yamete Ii Desuka Drama by Tomochika Kasaura". This research aims to provide information about characteristics, factors, and efforts of Akiko Hayase figure to tackle Generalized Anxiety Disorder (GAD). The methods used are descriptive analysis method and informal method. The theories used in analyzed are psychology literature theory by Wellek and Warren (2016), generalized anxiety disorder theory (DSM-IV-TR) by Davison (2014), psychoanalysis theory by Freud (2016), and semiotic theory by Danesi (2011). Based on the analysis result, there were five characteristics of GAD found in Akiko Hayase figure such as, 1) experiencing anxiety or worry to excessive; 2) feeling tired to easily; 3) irritability and offended; 4) nervous or have an pressure; 5) performing deviant acts. The GAD in Akiko Hayase figure was cause by psychoanalysis factors such as, 1) Feeling fear of being left by a loved one; 2) unfulfilled desires; 3) an memory in past failures. The behaviour-cognitive factors is rejection the existence of Akiko by Mizuki. The effort of Akiko Hayase figure to tackle GAD consist of internal effort such as, 1) trying to establish a harmonious relationship; 2) trying to have a skill. As for external effort such as, 1) trying to give calmness for Akiko; 2) trying to invite Akiko for start a new life.
\end{abstract}

Keywords: psychoanalysis, anxiety disorder, generalized anxiety disorder

\begin{abstract}
Abstrak
Penelitian ini berjudul "Generalized Anxiety Disorder Tokoh Akiko Dalam Drama Okaasan Musume wo Yamete Ii Desuka Karya Tomochika Kasaura". Penelitian ini bertujuan untuk memberikan informasi mengenai karakteristik, faktor penyebab dan upaya tokoh Akiko Hayase untuk mengatasi Generalized Anxiety Disorder (GAD). Metode penelitian yang digunakan adalah metode deskriptif analisis dan metode informal. Teori yang digunakan dalam menganalisis adalah teori psikologi sastra oleh Wellek dan Warren (2016), teori generalized anxiety disorder (DSM-IV-TR) oleh Davison (2014), teori psikoanalisis oleh Freud (2016), dan teori semiotika oleh Danesi (2011). Berdasarkan hasil analisis, terdapat lima karakteristik GAD yang ditemukan pada tokoh Akiko Hayase yaitu, 1) mengalami kecemasan atau kekhawatiran berlebih; 2) mudah merasa lelah; 3) mudah marah dan tersinggung; 4) gelisah atau mengalami tekanan; 5) melakukan tindakan menyimpang. GAD pada tokoh Akiko Hayase disebabkan oleh faktor psikoanalisis yaitu, 1) ketakutan akan ditinggalkan oleh orang terkasih; 2) keinginan yang tidak terpenuhi; 3) ingatan terhadap kegagalan di masa lalu. Faktor kognitif-behavioral yaitu penolakan terhadap keberadaan diri tokoh Akiko oleh Mizuki. Upaya tokoh Akiko Hayase dalam mengatasi GAD terdiri dari upaya internal yaitu, 1) berupaya untuk menjalin hubungan harmonis; 2) berupaya untuk menguasai suatu keterampilan. Adapun upaya eksternal yaitu, 1)
\end{abstract}


berupaya untuk memberikan ketenangan pada Akiko; 2) berupaya untuk mengajak Akiko memulai kehidupan yang baru.

Kata kunci: psikoanalisis, gangguan anxietas, generalized anxiety disorder

\section{Latar Belakang}

Manusia memiliki unsur-unsur kepribadian berupa perasaan positif dan negatif yang berperan untuk membantu proses perkembangan perilaku baik maupun buruk dalam kehidupan. Perilaku buruk terjadi akibat pengaruh perasaan negatif yang mendominasi setiap individu termasuk kaum wanita yang rentan mengalami perasaan negatif seperti kecemasan karena memiliki kelebihan dalam mengekspresikan segala perasaan. Perasaan cemas yang terus berlangsung dan tidak dapat dikendalikan mampu menimbulkan gangguan anxietas salah satunya adalah gangguan anxietas menyeluruh atau Generalized Anxiety Disorder (GAD). Penderita GAD terus menerus mencemaskan segala masalah serta memberikan reaksi berlebihan sehingga dikategorikan sebagai individu dengan perilaku abnormal. Perilaku seseorang yang normal lazimnya mengikuti irama kehidupan namun pribadi abnormal akan bertingkah laku menyimpang dari situasi lingkungan di sekitarnya (Minderop, 2013:10).

Kasus penyimpangan perilaku oleh penderita GAD ditemukan pada setiap negara, termasuk negara Jepang. GAD telah diderita sebagian masyarakat Jepang khususnya wanita sejak usia 17 tahun. Kasus GAD kemudian berhasil menginspirasi sutradara NHK World TV bernama Tomochika Kasaura untuk memproduksi drama televisi berjudul Okaasan Musume wo Yamete Ii Desuka dengan jumlah delapan episode dan memiliki durasi 48 menit di tahun 2017. Drama ini menceritakan tokoh Akiko Hayase yakni seorang ibu rumah tangga yang terus melakukan tindakan menyimpang kepada diri sendiri dan orang sekitarnya karena dipengaruhi oleh karakteristik GAD dalam dirinya. Drama ini dipilih sebagai objek data penelitian karena menyediakan data mengenai karakteristik, faktor penyebab, serta upaya tokoh untuk mengatasi GAD.

\section{Pokok Permasalahan}

Berdasarkan latar belakang yang telah diuraikan, maka dapat dirumuskan permasalahan sebagai berikut.

a) Bagaimanakah karakteristik GAD yang tergambar melalui tokoh Akiko Hayase dalam drama berjudul Okaasan Musume wo Yamete Ii Desuka karya Tomochika Kasaura?

b) Bagaimanakah faktor-faktor penyebab adanya GAD pada tokoh Akiko Hayase dalam drama berjudul Okaasan Musume wo Yamete Ii Desuka karya Tomochika Kasaura?

c) Bagaimanakah upaya yang dilakukan tokoh Akiko Hayase untuk mengatasi GAD dalam drama berjudul Okaasan Musume wo Yamete Ii Desuka karya Tomochika Kasaura?

\section{Tujuan Penelitian}

Penelitian ini bertujuan untuk meningkatkan apresiasi pembaca terhadap karya sastra Jepang berupa drama. Secara khusus penelitian ini bertujuan pula untuk mengetahui karakteristik, faktor-faktor penyebab serta upaya-upaya tokoh Akiko Hayase dalam mengatasi GAD pada drama berjudul Okaasan Musume wo Yamete Ii Desuka karya Tomochika Kasaura. 


\section{Metode Penelitian}

Prosedur pengumpulan data dalam penelitian ini adalah metode simak dan teknik catat. Metode deskriptif analisis kemudian digunakan pada tahap analisis data disusul dengan metode informal dan teknik narasi. Teori yang digunakan dalam menganalisis permasalahan yaitu pertama, teori psikologi sastra oleh Wellek dan Warren (2016) sebagai acuan dasar untuk memahami unsur kejiwaan tokoh Akiko. Kedua, teori generalized anxiety disorder oleh Davison (2014) digunakan untuk menjawab ketiga rumusan masalah mengenai karakeristik, faktor penyebab GAD, upaya-upaya tokoh Akiko dalam mengatasi GAD. Ketiga, teori psikoanalisis oleh Freud (2016) untuk mengetahui sistem kepribadian dominan antara $i d$, ego, dan superego yang berperan terhadap faktor serta upaya-upaya mengatasi GAD. Keempat, teori semiotika oleh Danesi (2011) mempermudah proses analisis melalui semiotika nonverbal tokoh yang terlihat melalui tanda-tanda dalam gambar.

\section{Hasil dan Pembahasan}

Bagian ini menguraikan hasil analisis meliputi karakteristik, faktor penyebab serta upaya dari tokoh Akiko Hayase untuk mengatasi GAD. Berikut uraian mengenai hal tersebut.

\subsection{Karakteristik GAD}

Karakteristik GAD terlihat melalui perubahan sifat serta penyimpangan perilaku. Hasil analisis data mengenai karakteristik GAD pada tokoh Akiko Hayase diuraikan sebagai berikut.

\subsubsection{Mengalami Kecemasan atau Kekhawatiran Berlebih}

Kecemasan atau kekhawatiran berlebih yang dimaksud dalam karakteristik pertama penderita GAD adalah adanya perasaan tidak wajar karena tidak mampu mengendalikan perasaan negatif. Hal itu ditandai dengan suatu perilaku yakni kecemasan saat berbicara seperti pada data berikut.

(1) 顕子: じゃ、本気なのね? もし。。 あなたにフラれて、美月が 傷ついて、自殺でもしたら って、それがとっても心配 なの。だからもし。。もし 本気でないんだったら、こ れ以上、関わらないでほし いのょ。

(第 2 課、40 分 58 秒)

Akiko: Ja,honkinanone?Moshi anata ni furarete, Mizuki ga kizutsuite, jisatsu demo shitaratte, sore ga tottemo shinpaina no. Dakara moshi.. moshi honki de naindattara, kore ijou, kakawaranaide hoshii no yo.

(Dai $2 \mathrm{Ka}, 40$ pun 58 byou) Akiko: Jadi, kau serius bukan? Mungkin kau akan menolaknya, Mizuki akan terluka, lalu mencoba bunuh diri, bukankah itu sangat mengkhawatirkan. Karena mungkin.. mungkin setelah perasaan yang serius itu tidak ada, pada akhirnya, semua hanya omong kosong.

(Episode 2, menit 40:58 detik)

Data (1) merupakan ungkapan perasaan cemas berlebih tokoh Akiko sebagai seorang ibu terhadap hubungan cinta antara Matsushima dengan Mizuki. Matsushima adalah tokoh laki-laki yang belum lama menyukai dan ingin memiliki hubungan lebih dekat dengan anak perempuan Akiko bernama Mizuki. Akiko menemui Matsushima secara terus-menerus di tempat ia bekerja untuk menyampaikan pendapat tentang 
peristiwa yang mungkin terjadi kepada Mizuki apabila hubungan keduanya tetap dilanjutkan. Kecemasan berlebih pada penderita GAD terlihat melalui topik pembicaraan yang berfokus pada kekhawatiran serta kemungkinan peristiwa di masa depan (Davison, dkk, 2014:200).

\subsubsection{Mudah Merasa Lelah}

Karakteristik kedua dari penderita GAD adalah mudah merasa lelah. Kelelahan merupakan kondisi penurunan daya tahan tubuh untuk beraktivitas akibat kondisi psikis-psikologi (Davison, dkk, 2014:52). Akiko diceritakan sebagai individu yang lemah. Ia pun sering ditemukan tidak sadarkan diri seperti pada data berikut.

(2) 文恵 : 美月ちゃん ‥

美月：お世話かけました。(急いで 顕子の部屋に入る)

文恵：びっくりしたわ。。突然、 倒れたから。

(第 3 課、12 分 9 秒)

Fumie : Mizuki-chan..

Mizuki : Osewakakemashita. (Isoide Akiko no heya ni hairu)

Fumie : Bikkurishitawa.. totsuzen, taoretakara.

(Dai $3 \mathrm{Ka}, 12$ pun 9 byou)

Fumie : Mizuki-chan..

Mizuki: Maaf telah merepotkan. (Bergegas masuk ke kamar Akiko)

Fumie : Aku benar-benar terkejut.. karena tiba-tiba ia pingsan.

(Episode 3, menit 12:09 detik)

Data (2) adalah ungkapan Fumie yakni sahabat Akiko yang menjadi orang pertama mendapati ia dalam keadaan tidak sadarkan diri. Tokoh Akiko diceritakan menerima telepon dari Fumie yang tidak sengaja membahas bahwa hubungan cinta antara Mizuki dan Matsushima kemungkinan sampai pada hal serius yakni pernikahan. Akiko yang mendengar hal itu, berkhayal apabila perkataan Fumie menjadi nyata sehingga ia tiba-tiba terjatuh dan pingsan. Seorang dengan GAD dapat tidak sadarkan diri apabila mengalami kelelahan kronis karena tidak mampu menahan perasaan cemas yang mengganggu pikirannya.

\subsubsection{Mudah Marah dan Tersinggung}

Perasaan mudah marah dan tersinggung adalah karakteristik ketiga dari seorang dengan GAD. Kemarahan merupakan puncak kegagalan individu dalam mengawal emosi sehingga menciptakan perilaku yang tidak menentu. Seseorang dapat mengontrol perasaan marah dalam dirinya namun, tokoh Akiko sebagai penderita GAD memilih untuk menghindari situasi tidak menyenangkan akibat perasaan marah seperti ditunjukkan melalui data berikut.

(3) 美月：ママが消えた。やっぱり私 に怒ってるの。ママどこに いるの。どうしていちばん 答えてほしい時にはいつも 答えてくれないの。生まれ て初めてだったママのいな い家なんて。

(第 3 課、46 分 19 秒)

Mizuki : Mama ga kieta. Yappari watashi ni okotteru no. Mama doko ni iru no. Doushite ichiban kotaete hoshii toki ni wa itsumo kotaete kurenai no. Umarete hajimete datta Mama no inai ie nante.

(Dai $3 \mathrm{Ka}$, 46 pun 19 byou)

Mizuki: Mama telah menghilang. Mungkinkah kau marah padaku? Mama kau ada 
dimana? Mengapa saat aku sangat ingin mendapatkan jawaban kau tidak pernah menjawabnya? Ini pertama kalinya sejak aku lahir Mama tidak ada di rumah.

(Episode 3, menit 46:19 detik)

\begin{abstract}
Data (3) menunjukkan bahwa Mizuki sedang berusaha mencari keberadaan Akiko yang tiba-tiba menghilang dan pergi meninggalkan rumah dalam jangka waktu yang lama. Mizuki pun berulang kali telah berusaha menghubungi namun sama sekali tidak mendapat jawaban dari Akiko. Seorang dengan GAD tidak dapat mengendalikan emosi ketika merasa marah, mereka cenderung bertindak tanpa arah seperti melarikan diri, menyerang, dan mengamuk kepada orang lain untuk menghilangkan perasaan tidak nyaman terhadap lingkungan maupun seseorang yang menjadi penyebab munculnya kemarahan.
\end{abstract}

\subsubsection{Merasa Gelisah atau Mengalami Tekanan}

Karakteristik keempat dari penderita GAD adalah merasa gelisah atau mengalami tekanan. Kegelisahan dapat menimbulkan tekanan perasaan secara berkelanjutan. Berikut data yang menunjukkan bahwa tokoh Akiko Hayase mengalami tekanan perasaan melalui perkataan orang terkasih.
(4) 玲子：どうしてできないの。ダメ な子ね。学校も希望校に入 れなかった。教師にもなれ なかった。旦那も大した事 なかった。
顕子：自分の娘にどんどんロが悪 くなるわ。どうするのよ。

玲子：何て言ったっけ？遠山さ ん？あの人と結婚してれば さ。あんたグズグズしてる から文恵ちゃんにとられち やった。

顕子：その話はやめてって言って るでしょ!

(第 4 課、12 分 5 秒)

Reiko : Doushite dekinai no. Damena ko ne. Gakkou mo kiboukou ni irenakatta. Kyoushi ni mo narenakatta. Danna mo taishita koto nakatta.

Akiko: Jibun no musume ni dondon kuchi ga warukunaru wa. Dousuru no yo.

Reiko : Nante ittakke? Tooyama san? Ano hito to kekkonshitereba sa. Anta guzuguzu shiteru kara Fumie chan ni torarechatta.

Akiko: Sono hanashi wa yamete tte itteru desho!

(Dai $4 \mathrm{Ka}, 12$ pun 5 byou)

Reiko: Kenapa kau tidak bisa melakukan apapun? Anak tidak berguna. Kau bahkan tidak bisa masuk ke sekolah favorit. Kau juga tidak bisa menjadi guru. Suami mu pun juga tidak banyak bisa diharapkan.

Akiko: Kau selalu saja berkata buruk pada putri mu. Kenapa kau melakukan ini?

Reiko: Bagaimana mengatakannya ya? Tooyama-san? Orang itu sudah menikah bukan. Karena lamban Fumie-chan merebutnya darimu.

Akiko: Bukankah aku sudah katakan berhenti membicarakan hal itu!

(Episode 4, menit 12:05 detik) 
Data (4) merupakan percakapan antara Akiko dengan ibu kandungnya yakni Reiko yang mengatakan bahwa ia adalah anak tidak berguna. Reiko diceritakan selalu memberi tekanan perasaan pada anaknya dengan mengungkap kembali memori kegagalan Akiko di masa lalu. Oleh karena itu, Akiko sangat membenci dan berusaha untuk berada jauh dari ibunya dengan cara memasukkan Reiko ke panti jompo seumur hidup. Penderita GAD yang pernah mengalami peristiwa buruk, merasa tertekan perasaannya apabila seseorang memberi ingatan kembali tentang kegagalan di masa lalu. Hal ini pun dapat mengganggu aktivitas penderita GAD sepanjang hidup.

\subsubsection{Melakukan Tindakan yang Menyimpang}

Tindakan menyimpang merupakan karakteristik kelima yang dilakukan oleh penderita GAD. Tokoh Akiko Hayase diceritakan bertindak menyimpang sehingga membuat orang lain merasa takut dan terancam terhadap keberadaan dirinya seperti pada data berikut.

(5) 美月：ママ。。いつもそうしてた

の。ずっと私を見張ってた

って事？怖かった。ママが

怖かった… (美月の心の 声)

(第 3 課、31 分 19 秒)

Mizuki: Mama.. itsumo sou shiteta no. Zutto watashi wo mihatte tatte koto? Kowakatta. Mama ga kowakatta.. (Mizuki no kokoro no koe)

(Dai $3 \mathrm{Ka}, 31$ pun 19 byou)

Mizuki: Mama.. apakah kau selalu melakukan hal ini? Secara terus menerus mengintai keberadaan diriku? Kau menakutkan. Mama kau benar-benar menakutkan. (Suara hati Mizuki)

(Episode 3, menit 31:19 detik)

Data (5) adalah ungkapan suara hati Mizuki terhadap perilaku Akiko. Mizuki berencana menemui Matsushima di sebuah cafe sepulang bekerja namun, tanpa sengaja dalam perjalanan, ia mendapati Akiko sedang mengintainya. Akiko diceritakan selalu ingin mengetahui kegiatan serta keberadaan Mizuki sehingga ia terus mengintai anaknya secara diam-diam. Mizuki yang mulai merasakan keanehan, berusaha sembunyi di balik papan nama sebuah kedai dan bergegas menyeberang ke sisi jalan yang lain ketika tokoh Akiko sedang memandang ke arah berlawanan. Penderita GAD tanpa ragu melakukan tindakan yang menyimpang seperti mengancam, mengintai, dan membunuh seseorang yang dianggap menjadi fokus kecemasannya.

\subsection{Faktor-faktor Penyebab GAD}

Karakteristik GAD yang muncul pada tokoh Akiko Hayase disebabkan oleh dua faktor yakni psikoanalisis dan kognitif-behavioral.

\subsubsection{Faktor Psikoanalisis}

Berikut uraian mengenai tiga hal penyebab munculnya GAD pada tokoh Akiko Hayase yang termasuk ke dalam faktor psikoanalisis.

\subsubsection{Ketakutan akan Ditinggalkan oleh Orang Terkasih \\ Kecemasan berlebih dalam diri tokoh Akiko terjadi karena adanya perasaan takut ditinggalkan seorang diri seperti ditunjukkan pada data berikut.}

(6) 顕子：ママを一人にしないでょ。 みっちゃん結婚しても一生 
一緒に住んでくれるって、 約束したもんね!

(第 4 課、22 分 3 秒)

Akiko: Mama wo hitori ni shinai de yo. Micchan kekkonshite mo isshou issho ni sunde kurerutte, yakusoku shita mon ne!

(Dai $4 \mathrm{Ka}, 22$ pun 3 byou)

Akiko: Mama tidak ingin sendiri. Kalau pun Micchan menikah, berjanjilah untuk tetap tinggal bersama seumur hidup, ya! (Episode 4, menit 22:03 detik)

Data (6) menunjukkan faktor kecemasan berlebih tokoh Akiko Hayase. Akiko diceritakan takut terhadap kesendirian sejak kecil karena ibunya sebagai orang tua tunggal lebih memilih pekerjaan dan sering meninggalkannya sendiri. Oleh karena itu, ia berusaha untuk menghindari perasaan takut ditinggalkan seorang diri dengan cara memohon pada Mizuki agar berjanji tidak meninggalkannya namun permohonan itu justru tidak terpenuhi. Faktor psikoanalisis yakni sistem id dalam kepribadian Akiko secara refleks memberi respon dengan berfokus pada rasa takut ditinggalkan seorang diri sehingga menimbulkan reaksi gugup saat memberi tanggapan pada lawan bicara (Freud, 2016:73).

\subsubsection{Keinginan yang Tidak Terpenuhi}

Akiko ingin memiliki suami berjabatan tinggi namun hal itu tidak dapat terwujud karena Kouji Hayase telah mengalami mutasi. Akiko pun berpaling pada Mizuki untuk dapat mewujudkan keinginan pribadi seperti ditunjukkan melalui data berikut.

(7) 浩司：甘かったです。顕子がいつ

$$
\text { もと変わらないのでちょつ }
$$

と落ち着いたかと安心して たんですが・..。僕がずるか

ったんです。仕事がうまく

いってなかったから顕子の

期待が美月に向いているの

が都合がょかったんです。

(第 6 課、22 分 51 秒)

Kouji: Amakatta desu. Akiko ga itsumo to kawaranai node chotto ochitsuita $\mathrm{ka}$ to anshinshitetan desu ga.. Boku ga surukattan desu. Shigoto ga umaku ittenakatta kara Akiko no kitai ga Mizuki ni muite iru no ga tsugou ga yokattan desu.

(Dai 6 Ka, 22 pun 51 byou)

Kouji: Sungguh manja. Karena Akiko tidak pernah berubah entah harus merasa lega atau tenang pun percuma.. Aku juga yang menjadi penyebab dari hal ini. Karena pekerjaan $\mathrm{ku}$ tidak berjalan dengan baik harapan Akiko berpaling pada Mizuki dan saat itu keadaannya justru menjadi lebih baik.

(Episode 6, menit 22:51 detik)

Data (7) adalah pernyataan yang diungkapkan oleh Kouji sebagai suami Akiko. Tokoh Akiko yang telah mengetahui bahwa suaminya mengalami mutasi sangat tidak ingin kehilangan Mizuki. Hal itu dilakukan dengan tujuan dapat memanfaatkan tenaga maupun hasil kerja keras anaknya untuk memenuhi segala keinginan pribadi tanpa memikirkan perasaan Mizuki. Akiko bahkan tega melakukan berbagai cara termasuk berbohong dan mengganggu kehidupan Matsushima yang dianggap menjadi musuh dalam memperebutkan Mizuki. Faktor psikoanalisis mendorong 
sifat ketergantungan Akiko (id) untuk mewujudkan proses pertahanan diri dengan cara bertindak menyimpang (ego) dalam memenuhi keinginan diri (Freud, 2016:35).

\subsubsection{Ingatan terhadap Kegagalan di Masa Lalu}

Fumie sebagai sahabat Akiko berperan sebagai penyebab adanya kegagalan di masa lalu yang terus mengganggu kehidupan Akiko seperti ditunjukkan pada data berikut.

（8）文恵：私、少し責任感じてるのよ ね。大学の時二人で同じ人 を好きになって卒業して私 が彼と結婚したでしょ。ど っちも負けたくなかっただ けかもしれない。結局、私 はたった一年で別れちゃっ たし。顕子はあれからます ます男の人に対して構える ようになった。

(第 2 課、29 分 15 秒)

Fumie: Watashi, sukoshi sekinin kanjiteru no yo ne. Daigaku no toki futari de onaji hito wo suki ni natte sotsugyou shite watashi ga kare to kekkon shita desho. Docchi mo maketakuna katta dake kamo shirenai. Kekkyoku, watashi wa tatta ichinen de wakare chattashi. Akiko wa are kara masumasu otoko no hito ni taishite kamaeru you ni natta.

(Dai 2 Ka, 29 pun 15 byou)

Fumie: Aku, merasa sedikit bertanggung jawab. Saat di Universitas kami berdua menyukai orang yang sama lalu setelah lulus aku menikah dengannya bukan. Mungkin aku hanya tidak ingin kalah dalam hal apa pun. Akhirnya, hanya dalam satu tahun aku sudah bercerai. Sejak itu Akiko jadi semakin berpura-pura terhadap perasaannya pada seorang laki-laki.

(Episode 2, menit 29:15 detik)

Data (8) menunjukkan perasaan bersalah Fumie yang menyebabkan Akiko mengalami tekanan terhadap kehidupan masa lalunya. Fumie dan Akiko menyukai pria yang sama bernama Tooyama saat di Universitas namun, Fumie berhasil menikah dengan pria tersebut dan mengkhianati perasaan Akiko. Sejak itu, Akiko yang sangat tertekan mulai kehilangan impian, ia tidak menunjukkan perasaan tulus kepada banyak pria termasuk Kouji, dan selalu mendapatkan perkataan buruk dari Reiko. Pribadi Akiko tidak mampu mengingat kembali individu dan peristiwa yang menyedihkan akibat pengaruh faktor psikoanalisis. Memori (id) mendapat paksaan untuk keluar dari kesadaran (ego) sehingga menimbulkan tekanan perasaan atau konflik yang menyakitkan dalam diri penderita (Freud, 2016:13).

\subsubsection{Faktor Kognitif-Behavioral}

Terdapat pula faktor kognitifbehavioral berupa penolakan terhadap keberadaan Akiko oleh Mizuki yang ditunjukkan pada data berikut.

(9) 美月：私、苦しいの! ママのそ

$$
\begin{aligned}
& \text { ばにいるのが苦しいの！ } \\
& \text { もうやめて ...も方帰って。 } \\
& \text { 二度と来ないで! }
\end{aligned}
$$

(第 6 課、 1 分 18 秒)

Mizuki:Watashi, kurushii no! Mama no soba ni iru no ga kurushii 
no! Mou yamete.. Mou kaette. Ni do to konaide!

(Dai $6 \mathrm{Ka}, 1$ pun 18 byou)

Mizuki: Aku, merasa sengsara! Aku sunggu sengsara karena keberadaan dirimu Mama! Hentikan, sudah pulanglah. Jangan pernah datang untuk kedua kalinya!

(Episode 6, menit 01:18 detik)

Data (9) adalah ungkapan Mizuki kepada Akiko. Tokoh Mizuki diceritakan pergi meninggalkan rumah dan tinggal bersama Matsushima karena merasa sengsara dengan keberadaan ibunya. Sikap Akiko yang selalu menentang hubungan cinta dan memaksakan kehendak pada dirinya membuat Mizuki harus mengambil keputusan yakni pergi dari rumah untuk menghindar dari tekanan ibunya. Faktor kognitif-behavioral terjadi karena tokoh Akiko Hayase mempersepsikan suatu pernyataan buruk pada dirinya sebagai ancaman terhadap keseimbangan psikis (ego) sehingga mampu menimbulkan karakteristik GAD.

\subsection{Upaya-upaya Mengatasi GAD}

Tokoh Akiko Hayase secara perlahan diceritakan mulai memiliki keinginan kuat dari dalam dirinya untuk kembali menjadi pribadi normal. Oleh karena itu, ia pun berusaha untuk merealisasikan dua upaya yakni pertama, upaya secara internal meliputi menjalin hubungan harmonis kembali bersama orang terkasih melalui permohonan maaf, mewujudkan keinginan bersama dan mengintrospeksi diri. Akiko juga berusaha untuk menguasi sebuah keterampilan membuat boneka demi mengalihkan perasaan cemas berlebih. Kedua, upaya secara eksternal diperoleh melalui bantuan orang terkasih yang selalu memberikan perasaan tenang dan mengajak tokoh Akiko untuk memulai kehidupan baru bersama orang-orang baru dalam lingkungan yang berbeda.

\section{Simpulan}

Berdasarkan data yang telah dianalisis ditemukan lima karakteristik GAD pada diri tokoh Akiko Hayase yaitu, 1) kecemasan atau kekhwatiran berlebih; 2) mudah merasa lelah; 3) mudah marah dan tersinggung; 4) gelisah dan mengalami tekanan; 5) melakukan tindakan yang menyimpang. Selain itu, terdapat dua faktor penyebab Akiko mengalami GAD yakni pertama, faktor psikoanalisis berupa ketakutan ditinggalkan seorang diri oleh orang terkasih, permintaan yang tidak terpenuhi, serta ingatan terhadap kegagalan di masa lalu. Kedua, faktor kognitif-behavioral berupa penolakan terhadap diri Akiko yang diungkapkan secara langsung oleh Mizuki.

Hal ini disebabkan karena id dipengaruhi oleh lingkungan dan objek yang menjadi penyebab munculnya GAD sehingga ego membangkitkan pemikiran negatif dan menjalankan tindakan menyimpang. Adapun upaya-upaya yang dilakukan oleh tokoh Akiko Hayase dalam mengatasi GAD yakni pertama, upaya internal berupa menjalin hubungan harmonis dan menguasai keterampilan membuat boneka.

Kedua, upaya eksternal yang diperoleh melalui bantuan orang terkasih berupa memberikan perasaan tenang dengan menyembunyikan objek penyebab kecemasan serta membujuk Akiko untuk ikut memulai kehidupan baru di Indonesia, bertemu orang-orang baru dalam lingkungan dan situasi yang berbeda sebagai karyawan sebuah pabrik lokal. Superego menjadi kepribadian dominan yang berhasil membangkitkan perasaan bersalah maupun penyesalan serta mengarahkan ego pada tujuan 
positif yang dapat diterima oleh orangorang sekitarnya. Tokoh Akiko Hayase pun dapat menjadi individu dengan kepribadian normal kembali.

\section{Daftar Pustaka}

Davison, Gerald C dkk.2014.Psikologi Abnormal Edisi-9.Diterjemahkan oleh Noermalasari Fajar.Jakarta: PT RAJA GRAFINDO PERSADA

Danesi, Marcel. 2011. Pesan, Tanda, dan Makna: Buku Teks Dasar Mengenai Semiotika dan Teori Komunikasi. Yogyakarta: Jalasutra

Freud, Sigmund.2016.Psikoanalisis Sigmund Freud (diterjemahkan oleh K.Bertens).Jakarta: PT Gramedia Pustaka Utama

Minderop, Albertine .2013.Psikologi Sastra - Karya Sastra, Metode, Teori, dan Contoh Kasus.Jakarta: Yayasan Pustaka Obor Indonesia

Wellek, Rene dan Warren, Austin.2016. Teori Kesusastraan. Diterjemahkan oleh Melani Budianta. Jakarta: PT Gramedia Pustaka Utama 